\title{
LICHEN INVENTORY OF WHITE ROCKS OPEN SPACE (CITY OF BOULDER, COLORADO)
}

\author{
Erin A. Tripp ${ }^{1}$
}

\begin{abstract}
A lichen inventory of White Rocks Open Space (City of Boulder, CO), a unique outcropping of exposed unstable sandstones, is presented. White Rocks is an ecologically important, $\sim 40.5$-ha (100-acre) protected area whose biological significance is in part attributable to geological and climatological history as well as degree of preservation, but also because it represents a biodiversity reservoir in a sea of agriculture and urban development. This inventory resulted in documentation of 56 species, including 1 new record to the United States, 1 new record to Colorado, 2 species new to science, and 2 additional species potentially new to science pending further study. Several species, though common at White Rocks, are locally rare within Boulder County and the Front Range Mountains of Colorado owing to a paucity of exposed sandstone. Such species instead have affinities to habitats more typical of eastern and far western Colorado, such as the state's high plains and sage-juniper scrub. A checklist of the 56 species is presented along with an assessment of taxon abundance and preliminary delimitation of 5 lichen communities. General discussion of ecology and management recommendations is provided. The present study is intended to begin the process of more fully documenting the lichen biota of Boulder City, Boulder County, and surrounding areas. Data herein also contribute new knowledge to the North American lichen biota as a whole via a comprehensive inventory of a sandstone formation, of which there exist relatively few. The inventory highlights the ecological significance of Open Space programs nationwide, particularly those in densely populated areas such as the Denver-Boulder-Longmont urban triangle. The discoveries reported here were made within a 10-min drive of the University of Colorado, demonstrating the potential for further discovery in Colorado lichenology.
\end{abstract}

Resumen.-Presentamos un inventario de líquenes de White Rocks Open Space (Ciudad de Boulder, Colorado), un afloramiento único de areniscas blandas expuestas. White Rocks es una área ecológica protegida importante de 40.5 ha (100 acres) de extensión, cuya importancia biológica es atribuible, en parte, a su historia geológica y climatológica, así como a su nivel de preservación, y a que representa una reserva de biodiversidad en un océano de agricultura y desarrollo urbano. Este inventario resultó en la documentación de 56 especies, incluyendo 1 nuevo registro en Estados Unidos, 1 nuevo registro en Colorado, 2 nuevas especies para la ciencia y, a la espera de nuevos estudios, 2 especies adicionales potencialmente nuevas para la ciencia. Varias especies, aunque habituales en White Rocks, raramente se localizan en el Condado de Boulder y en las Montañas Front Range de Colorado debido a la escasez de piedra arenisca expuesta. De hecho, estas especies tienen afinidad con hábitats más típicos del este y el lejano oeste de Colorado, como las llanuras y las arboladas de salvia y enebros del estado. Presentamos un listado de las 56 especies, junto con una evaluación de la abundancia del taxón y la delimitación preliminar de 5 comunidades de líquenes. Se proporciona una discusión general sobre la ecología y proporcionamos recomendaciones para su manejo. El presente estudio tiene como objetivo iniciar el proceso de documentación de la biota de líquenes de Boulder City, el condado y sus alrededores de forma más completa. Los datos que presentamos también contribuyen al nuevo conocimiento de la biota de líquenes de América del Norte a través del inventario completo de una formación de piedra arenisca, sobre las cuales existen relativamente pocos inventarios. El inventario que se describe aquí destaca la importancia ecológica de los programas de Open Space (Espacio Abierto) a lo largo del país, sobre todo aquellos llevados a cabo en zonas densamente pobladas, como el triángulo urbano Denver-Boulder-Longmont. Los descubrimientos aquí documentados se realizaron a una distancia de 10 minutos en automóvil de la Universidad de Colorado, lo que demuestra el potencial de futuros descubrimientos sobre liquenología en Colorado.

The Southern Rocky Mountains and adjacent prairies of Colorado (EPA Level III Ecoregions; Chapman et al. 2006) are characterized by a mosaic of environments typical of many montane portions of North America, particularly western North America (Will-Wolf et al. 2006). Boulder County alone ranges in elevation from under $1524 \mathrm{~m}(5000 \mathrm{ft})$ to over $4267 \mathrm{~m}(14,000 \mathrm{ft})$, traversing mixed grass prairies (with tallgrass relicts), submontane forested foothills, and alpine environments above treeline. Among these dominant vegetation zones are patches of much rarer habitat types, such as outcroppings of sandstone or

${ }^{1}$ University of Colorado, Department of Ecology \& Evolutionary Biology and Museum of Natural History, UCB 350, Boulder, CO 80309. E-mail: erin.tripp@colorado.edu 


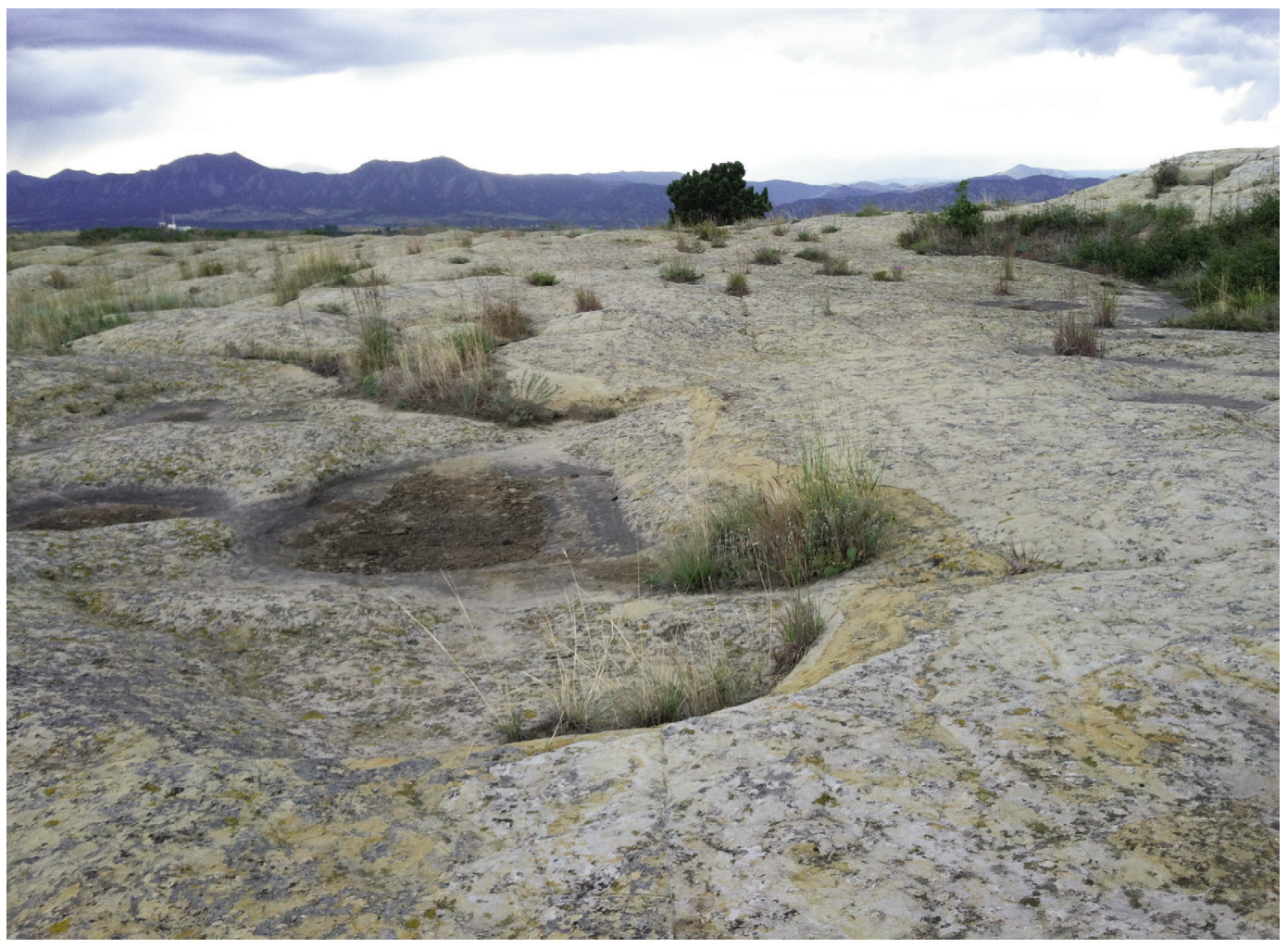

Fig. 1. Western end of sandstone outcropping at White Rocks Open Space, showing depressions and rises typical of large, upper rock shelf. The iconic "Flatiron" mountains of the City of Boulder toward the west are seen in background.

shale, eastern woodland relict forests, and fens. Given this biological mosaic and the general ecological significance of Colorado's native habitats, the lichen biota of the state is expected to be particularly rich and representative of numerous other ecosystems of western North America. Yet, a comprehensive account of lichens in Colorado is lacking. Instead, most literature on the biota exists as taxon-specific reports of occurrences. Shushan and Anderson (1969) provided the only attempt at a full checklist of the state's lichens (448 species treated), but this work was based entirely on literature reports rather than verification of specimens held in herbaria. Beyond this, there have been a limited number of regional inventory efforts (Anderson 1962, Dakota Sandstone; Egan 1970, Mt. Audubon alpine; Hale 1982, Flat Tops Wilderness Area; McCune et al. 1998, macrolichens associated with the USFS's Forest Health Monitoring Proram; Shrestha and St. Clair 2009, San Juan-Rio Grand National Forest; see additional references listed in Shushan and Anderson 1969, as well as a review of lichenological inventory work in Colorado presented in Shrestha and St. Clair 2009). The present contribution adds to the list of local or regional inventories in the state and serves as initial steps toward a revision of the lichen biota of Boulder County and surrounding areas.

\section{White Rocks Open Space}

White Rocks Open Space (Fig. 1) represents an 40.5-ha (100-acre) ecologically important protected area, situated within and proximal to the eastern limits of the City of Boulder, Colorado. Its biological significance is in part attributable to its geological history, climatological history, and degree of preservation (MacPhail et al. 1970), but also because it represents an important biodiversity reservoir in a sea of agriculture and urban development (i.e., the Boulder-Denver-Longmont urban triangle). White Rocks is a rare and fragile outcropping of sandstone that rises directly 
above the northern margin of Boulder Creek. The outcropping itself consists of a large 1- to 2-tiered sandstone shelf, with both horizontal and vertical exposed surfaces, and is $\sim 1000 \mathrm{~m}$ in length oriented east-west. This prominent outcropping is flanked by a slightly more minor adjacent sandstone exposure directly to the east, which is some $\sim 800 \mathrm{~m}$ in length. The outcrops belong to the Fox Hills Sandstone of the Laramie Formation, dating to $\sim 67$ million years (MacPhail et al. 1970, Weimer 1973, Hirschfeld 2013a, 2013b). The sandstone at White Rocks is, as the name implies, very white in color and composed primarily of quartz with minor amounts of montmorillinite clay. The White Rocks outcropping is known in particular for its peculiar jointed polygons or "turtlebacks" that characterize horizontal surfaces of the exposed rock (Fig. 2). These polygons are thought to be derived from fluctuating levels of moisture content in the montomorillinite clay, which combine with other environmental factors to induce stresses and cracks, culminating in polygons (Netoff 1971). The sandstone itself is extremely fragile and susceptible to weathering by foot travel or natural phenomena such as strong rains or high winds, but its erosion is slowed substantially by characteristic "case hardening" of the superficial-most surfaces of the turtlebacks, which derives from hardened clay strengthened by a biotic crust-primarily lichens.

Despite the small geographic size of White Rocks, the preserve is known to harbor several rare vascular plants as well as invertebrates, likely because of microhabitat diversity therein represented (Byars 1936, Weber 1949, 1970, Clark et al. 2001). Microhabitat differentiation at White Rocks is attributable to small-scale variation in relative humidity and water availability, exposure to wind and sun, mineral content, aspect and steepness of slopes (MacPhail et al. 1970), and the biotic environment itself. Examples of microhabitats represented at White Rocks include (1) large sandstone surfaces exposed to high radiation and winds intermixed with (2) shaded, deep to shallow crevices, (3) steep walls and ledges with overhangs that border riparian forests below, (4) large bowl-shaped depressions and smaller depressions (including turtlebacks) that become short-term catchments for water, (5) regions of sandstone with naturally higher clay content (and thus higher water-holding capacity), (6) regions of sandstone with greater case hardening attributable to evaporative processes, clay content, and biotic crusts that leave behind a substrate that is more resistant to weathering, (7) bands of separation between Fox Hill Sandstone formations interrupted by exposed Pierre shales, and finally (8) mineral inclusions (chert or calcareous material) that form concretions and are intermixed among sandstones. Based on this diversity of microhabitats, the existing knowledge of the biota of White Rocks, and research elsewhere that has documented rich and unique lichen biotas on comparable sandstone formations (Fink 1904, Gilbert 1980, Showman 1987, Clark et al. 2001), White Rocks is hypothesized to host a unique community of lichens that is unrepresented or underrepresented in Boulder County, as well as across the state. Indeed, other sandstone outcrops in North America host rare or unusual species of lichens such as Dibaeis absoluta and Ramalina petrina (Skorepa 1973, Showman 1987).

Despite a history of research and general interest in the White Rocks Open Space, no inventory or assessment of lichens of this unique outcropping has been conducted. The most relevant prior works regarding the lichen biota of the immediate area (Colorado's "Front Range") are those of Anderson (1962) and Weber (in Hogan 1993). Anderson (1962) surveyed lichens of the Dakota sandstone of north central Colorado but excluded many crustose species from that work. Weber (in Hogan 1993) provided a synoptic list of the lichens of Boulder's Mountain Parks, but this list lacks numerous species (especially crustose taxa) and taxonomy therein is outdated. Thus, the objective of the present investigation was to conduct an inventory of lichens of White Rocks Open Space. This inventory builds baseline information about the biodiversity of this important preserve, enables long-term conservation planning and resource management in a data-driven manner, facilitates future lichen taxonomic and ecological research in the area, and improves our capacity to educate the broader public about the importance of lichens in urban environments.

\section{Methods}

Between June and September 2014, a lichen inventory of White Rocks Open Space (City of 


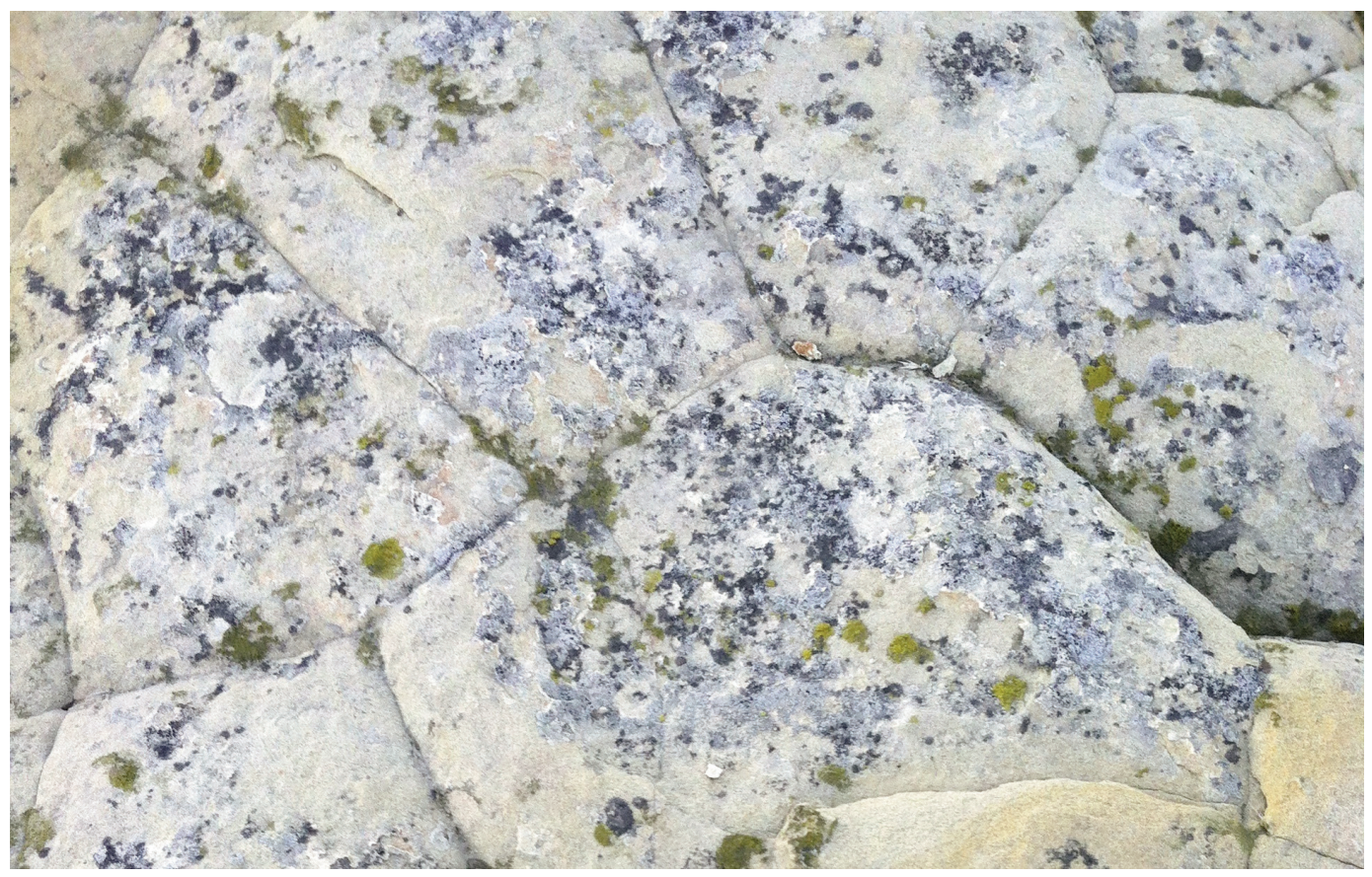

Fig. 2. Turtlebacks (polygons) characteristic of horizontal surfaces at White Rocks, derived from fluctuating levels of moisture content in the montomorillinite clay, which combine with other environmental factors to induce stresses and cracks.

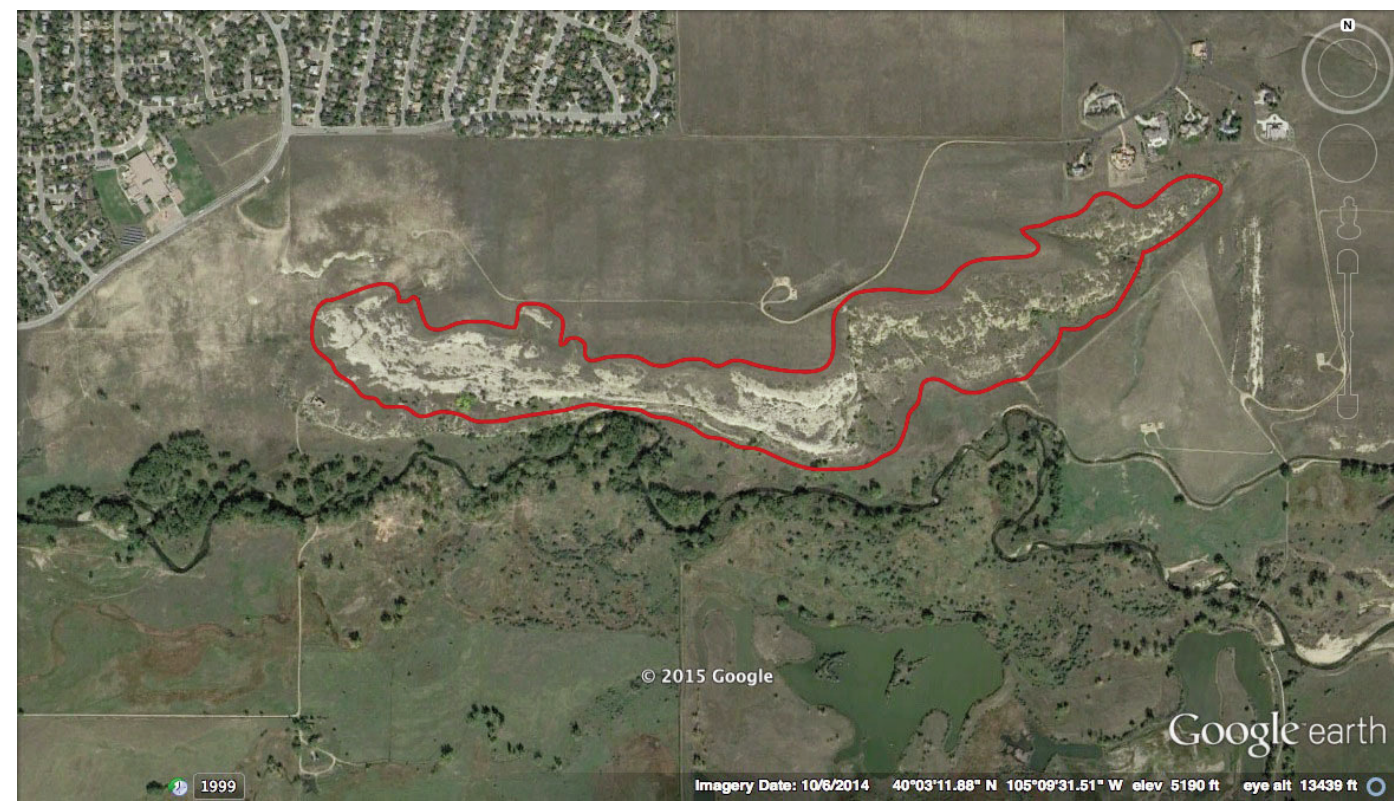

Fig. 3. Approximate boundaries of the White Rocks lichen inventory (red outline), which closely mirrors the area delimited by Boulder as the White Rocks Conservation Target. 
Boulder, CO) was conducted over the course of 6 site visits. The area covered by this survey was $\sim 40.5$ ha (100 acres) (Fig. 3). The inventory was conducted primarily via new field collections rather than existing museum specimens, given the lack of adequate representation of this site among lichen herbaria (www lichenportal.com), including the University of Colorado Herbarium (COLO). Occasional historical specimens from White Rocks housed at COLO were additionally studied as part of this work but yielded no additional species beyond those discovered during fieldwork (see Results).

Lichens were sampled using standard field collection techniques employed in previous studies (e.g., Lendemer and Tripp 2008, Lendemer et al. 2013). All accessible habitats and substrates contained within the $\sim 40.5$-ha $(100$-acre) preserve were targeted (i.e., the upper and lower flat rock outcrops, the immediately adjacent accessible portions of vertical rock faces, the lower floodplain zone that is densely vegetated and has few exposed rocks, and the adjacent prairie habitats including soil and plant substrates). To capture total diversity as best as possible, terricolous (soil), saxicolous (rock), corticolous (bark), and lignicolous (decaying wood) substrates were sampled. However, given the fragile nature of rock surfaces and the relatively small size of the preserve, care was taken to (1) remove small amounts of material for vouchers and to do so away from a pathway that is used by staff members for tours and monitoring, and (2) make only the minimal number of voucher specimens needed to produce a complete inventory (i.e., a given species was sampled only once unless additional collections were needed to confirm identifications, as in the case for several crustose species). Care was also taken to avoid the general area of a longterm Bald Eagle nest atop a large snag on the northern margin of Boulder Creek. Locality, habitat, substrate, and ecological data were recorded for all vouchers. Additionally, I estimated taxon abundance on a quantitative to qualitative scale with 5 rankings: rare, infrequent, occasional, common, and abundant. A species that was seen only once was considered rare, whereas a species that was seen $2-4$ times was considered infrequent. Rankings of occasional, common, and abundant were assessed qualitatively rather than based on the precise number of thalli seen. All collections were photographed in the field using a Nikon D7100 digital SLR with a 105-mm 1:1 macrolens and ring flash, in preparation for a field guide (Tripp in press). One to 2 vouchers per collection were made, and the primary set of specimens is deposited at the University of Colorado Herbarium, Museum of Natural History. Taxonomy and nomenclature follow Esslinger (2014) for the most part.

Chemistry was studied using standard spot test reagents as outlined in Brodo et al. (2001). Thin Layer Chromatography was conducted using Solvent C as outlined by Culberson and Kristinsson (1970). Measurements and micrographs of macroscopic and microscope structures were made as needed for identifications using an Olympus SZX10 stereomicroscope and an Olympus BX51 compound epifluorescence microscope equipped with a Retiga 2000R imaging system. Thin sections of thalli and ascomata were made by hand using a razor blade then mounted in water or iodine.

\section{RESULTS}

A total of 82 collections were made and photographed in the field, and the collections yielded 56 species of lichens (Table 1). The total number of species on a given substrate was as follows: 50 saxicolous, 4 corticolous, and 2 terricolous. Of the 56 species, 40 were crustose, 11 were foliose, 4 were squamulose, and 1 was fruticose. On an abundance scale with 5 rankings, the number of species per ranking was as follows: 9 abundant, 9 common, 19 occasional, 12 infrequent, and 7 rare (Table 1). These 82 collections also yielded 2 species new to science (Tripp and Lendemer 2015), 2 additional species putatively new to science (currently under further investigation), 1 new report to the United States, and 1 new report to Colorado (Table 1).

\section{Discussion}

The present study serves as the first documentation of the lichen biota of a rare sandstone formation in Boulder County, Colorado. Somewhat remarkably, there have been very few lichen inventories of sandstone formations in North America. By far the most relevant to the present study was that of Anderson (1962), who inventoried the Dakota sandstone formation of northern Colorado. He documented 


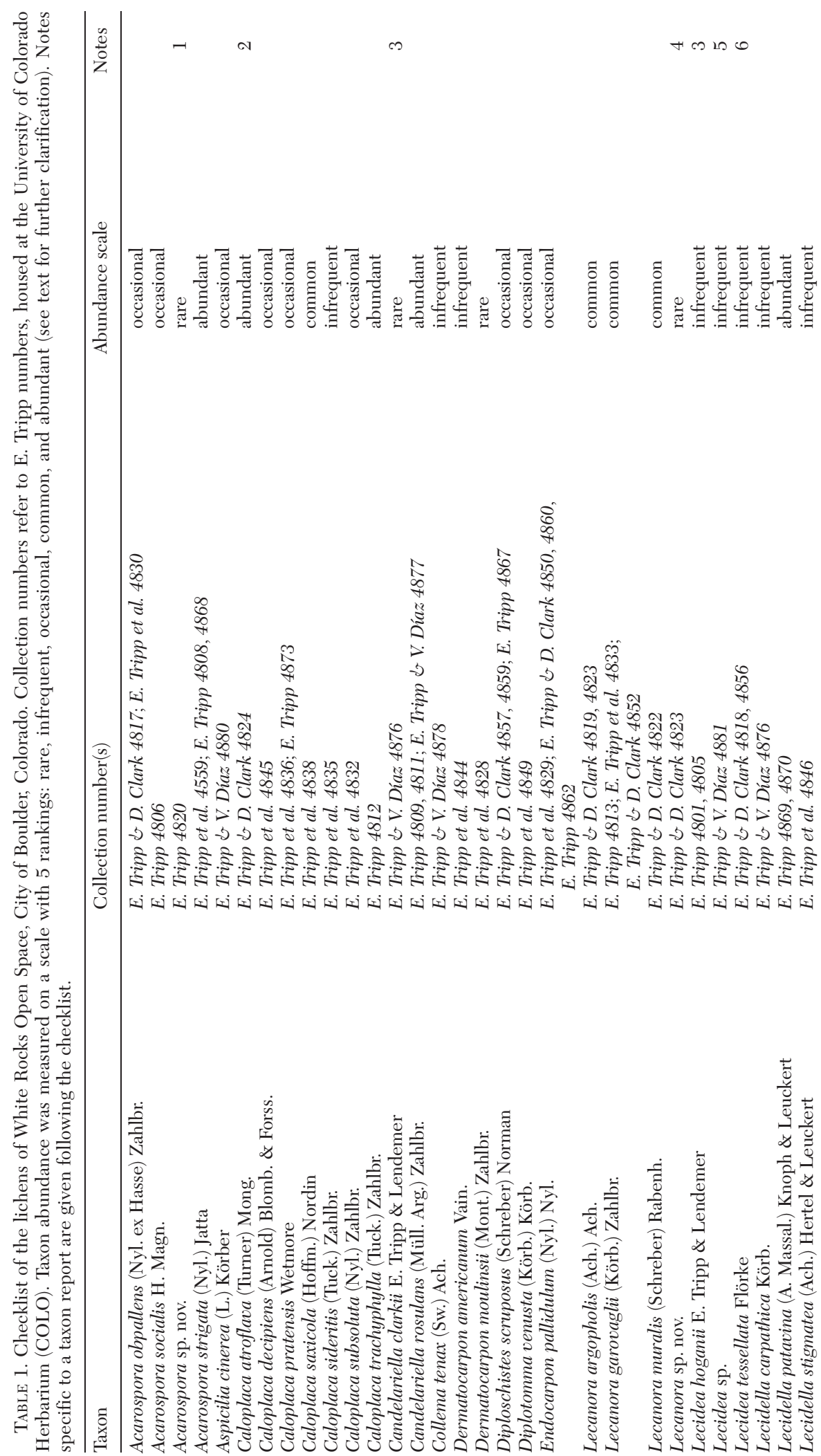




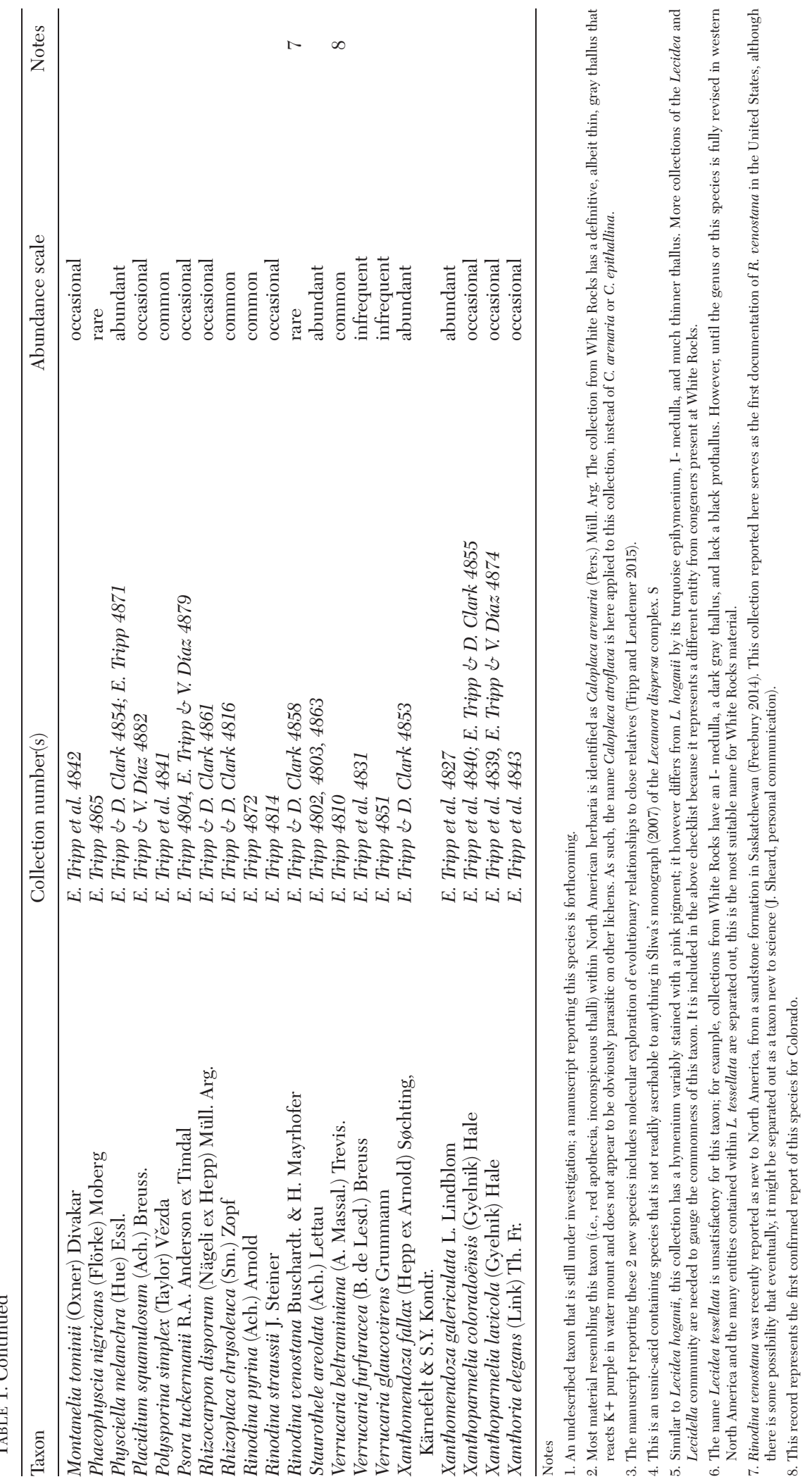


130 species over a stretch of $\sim 105 \mathrm{~km}(65 \mathrm{mi})$, ranging from Boulder northwards along the Front Range of the Rocky Mountains (see additional reports of psammophilous species added by Anderson and Carmer 1974). Beyond Anderson's study, Hale (1982) studied the lichens of Flat Tops Wilderness Area in Routt and White River National Forests, Colorado, but only a portion of the survey area contains exposed sandstone. Fink (1904) studied the lichen composition of sandstone riprap habitat in Iowa, an artificial habitat some 30 years old at the time of Fink's work. Showman (1987) studied the macrolichens of Crane Hollow in Ohio, but that site was mostly forested and contained only very small outcroppings of sandstone. Finally, Rushforth et al. (1982) studied the lichens of Zion National Park and found that species diversity was highest on sandstone boulders, but that study was ecological rather than taxonomic and no checklist was presented. Thus, the present contribution fills a niche among modern lichen checklists within North America.

\section{Lichen Communities of White Rocks}

A preliminary circumscription of lichen communities present at White Rocks is presented below. These communities are not based on quantitative composition data (e.g., see Will-Wolf et al. 2006), nor are they interpreted in light of environmental variables and variation present at White Rocks. Rather, it is intended that the discussion below serves as a first pass at understanding general community types, which can then be used by ecologists during furture attempts to more quantitatively define lichen communities at the site. These preliminary community circumscriptions can also be used by Open Space management staff in conservation or other ecological studies of the White Rocks lichen biota.

Five lichen communities present at White Rocks are described below; the first 3 are relatively common, whereas the last 2 are minor. Conspicuously absent from White Rocks were common species of the lower montane foothills of Boulder County with affinity to moister environments (e.g., north-facing slopes) such as Nephroma parile, Parmelia saxatilis, Peltigera canina, Physconia enteroxantha, Physconia muscigena, and Protoparmelia badia.

Horizontal, Loose Sandstone (HLS).This was by far the most commonly available surface and also represents the most diverse lichen community at White Rocks. The fragile nature of this community suggests that several of the constituent lichens could be thought of as biotic soil crusts with important ecological roles in slowing erosion. The following species are common constituents of HLS: Aspicilia cinerea, Acarospora strigata, Caloplaca atroflava, Caloplaca pratensis, Candelariella rosulans, Lecanora argopholis, Lecanora garovaglii, Lecanora muralis, Lecidea patavina, Xanthoparmelia coloradoënsis, Xanthoparmelia lavicola. This community is dominated by Candelariella rosulans and Lecidea patavina.

Tilted, Hard Sandstone (THS).--Boulders of varying sizes and consisting of sandstone that is conspicuously harder in texture than HLS dominate portions of the upper shelf at White Rocks. Lichens within this community occur on tilted to vertical surfaces, or on the tops of these boulders. The following species are common constituents of THS: Acarospora obpallens, Acarospora socialis, Caloplaca saxicola, Caloplaca trachyphylla, Dermatocarpon americanum (usually in rock crevices), Diploschistes scruposus, Diplotomma venustum, Lecanora flowersiana, Lichinella stipatula, Montanelia tominii, Polysporina simplex, Psora tuckermanii (always in rock crevices), Rhizocarpon disporum, Rhizoplaca chrysoleuca, Rinodina straussii, Staurothele areolata, and Xanthomendoza trachyphylla. This community is dominated by the small but pervasive crustose species Staurothele areolata.

Shaded Rock Overhang (SRO).-This habitat is limited in both size and lichen diversity at White Rocks. The only species that is dominant in large, shaded rock overhangs is Lepraria finkii.

SoIL Crust (SC).-At White Rocks, there is a conspicuous community of lichens that only inhabit the junction where sandstone and vegetation meet. These species also extend onto terricolous substrates of vegetated soils. This community represents biotic soil crusts in the strict sense of the phrase, but note that numerous species of the HLS community also fall under the scope of biotic soil crust communities given the extremely loose and fragile nature of those horizontal sandstone surfaces. The SC community consists primarily of Endocarpon pallidulum and Placidium squamulosum.

Corticolous Surface (CS).- - The corticolous biota at White Rocks was, together 
with SROs, the most species-poor of all 5 communities (corticolous substrates were similarly poor in McCune et al. 1998). Celtis reticulata, Oligosporus filifolius, and Rhus trilobata were the most important vascular plant substrates. The following 4 species dominate the CS community: Physciella melanchra, Rinodina pyrina, Xanthomendoza fallax, and Xanthomendoza galericulata.

Rare and Unusual Lichens at White Rocks

Although many species found at White Rocks are relatively common in similar habitats of western North America, sandstone outcroppings are unusual in the Front Range Mountains of Colorado. Given this, species such as Acarospora obpallens, Endocarpon pallidulum, Lecidella carpathica, Lecidella stigmatea, Lichenella nigritella, Lichenella stipatula, Phaeophyscia nigricans, and Verrucaria furfuracea are relatively uncommon elements of the local lichen biota and can be found more commonly in more arid portions of the state, such as prairies and sagebrush or juniper scrub.

Four species at White Rocks represent taxa unknown to science or putatively unknown to science. Two of these, Candelariella clarkii and Lecidea hoganii, were treated in detail in Tripp and Lendemer (2015). Two others (Acarospora sp. and Lecanora sp.) are under further investigation and will be treated in a future manuscript. Both the new Candelariella and the new Lecidea are extremely rare at White Rocks: the former was found only once and the latter only twice. Extensive searches through suitable named and unnamed material in the COLO Herbarium failed to produce further specimens that can be attributed to these species. As such, it is likely that both species are rare locally and globally, and we have recommended that both be considered Critically Endangered under current IUCN conservation assessment guidelines (Tripp and Lendemer 2015). Recent work at other exposed sandstone sites of the Fox Hills Formation has similarly yielded new, rare species (Westberg et al. 2011). Finally, Rinodina venostana represents the first report of this taxon from the United States, and Verrucaria beltraminiana represents the first confirmed report of this species for Colorado (see Table 1).

This inventory demonstrates that sandstone habitats in the Southern Rockies are underexplored lichenologically yet host diverse and unique communities. Moreover, these discoveries were made within a 10-min drive of the University of Colorado, whose herbarium hosts one of the largest and most active collections of lichens in western North America. This demonstrates the potential for discovery that remains in Colorado, even within or near dense urban areas.

\section{Conclusions}

The present study represents one of the most comprehensive, modern lichen inventories of a site within or around the Southern Rocky Mountain ecoregion. The primary purpose of this research was to provide a checklist of the lichens of this unusual habitat that can be used by the City of Boulder's Open Space and Mountain Parks research and administrative staff in managing, protecting, and continuing to learn from our local biological resources. It is anticipated that this study will open additional avenues of lichen research and conservation at White Rocks. With a baseline now in place, these data will for example enable a study of lichen succession in an area with already higher-than-average rates of erosion. Additionally, as comprehensive inventories of additional sites are made and become available, these data will contribute to future calculations of biodiversity statistics across the state (e.g., levels of alpha and beta diversity and impacts of ecological and climatological gradients on lichen biodiversity).

White Rocks hosts a rich and, within Boulder County, unique lichen community. Sandstone formations are particularly sensitive landscapes. Excessive foot traffic, thin soils, and high rates of erosion create a relatively unstable environment and one with potentially slower rates of regeneration. Given recent development and continued habitat destruction throughout North America, the lichen inventory described herein is particularly timely and highlights the ecological significance of Open Space programs nationwide, particularly those in densely populated areas such as the Denver-Boulder-Longmont urban triangle.

\section{ACKNOWLEDGMENTS}

I thank first and foremost the City of Boulder's Open Space and Mountain Parks Program 
for their years of dedication and funding towards the preservation of native habitats in Boulder, Colorado. In particular, Lynn Riedel was instrumental in facilitating this inventory. Megan Bowes provided further support for building knowledge of the local lichen biota. Dina Clark, Vanessa Díaz, and James Lendemer are thanked for their field contributions. Sue Hirschfeld provided helpful geological information. I am indebted to James Lendemer, Kerry Knudsen, Ted Esslinger, John Sheard, and Othmar Breuss for contributing some of the identifications. Finally, I thank Caleb Morse and Richard Harris for discussion on several species. This research was funded by a grant from Boulder's Open Space and Mountain Parks Program.

\section{Literature Cited}

Anderson, R.A. 1962. The lichen flora of the Dakota Sandstone in north-central Colorado. Bryologist 65:242-261.

Anderson, R.A., and M.B. Carmer. 1974. Additions to the lichen flora of Colorado. Bryologist 77:216-223.

Brodo, I.M., S.D. Sharnoff, and S. Sharnoff. 2001. Lichens of North America. Yale University Press, New Haven, CT.

BYARS, L.F. 1936. An ecological study of the ants of Boulder County, Colorado. Master's thesis, Department of Biology, University of Colorado.

Chapman, S.S., G.E. Griffith, J.M. Omernik, A.B. Price, J. Freeouf, AND D.L. Schrupp. 2006. Ecoregions of Colorado [map scale 1:1,200,000]. U.S. Geological Survey, Reston, VA.

Clark, D.A., C. Crawford, and W.F. Jennings. 2001. Draft baseline plant survey of White Rocks and surrounding area in eastern Boulder County. Unpublished report prepared for the City of Boulder Open Space and Mountain Parks Department.

Culberson, C.F., and H.D. Kristinsson. 1970. A standardized method for the identification of lichen products. Journal of Chromatography 46:85-93.

Egan, R.S. 1970. Alpine lichens from Mt. Audubon, Boulder County, Colorado. Bryologist 73:385-389.

EsSLINGER, T.L. 2014. A cumulative checklist for the lichenforming, lichenicolous and allied fungi of the continental United States and Canada. North Dakota State University, Fargo, ND; [accessed 23 March 2014]. http:// www.ndsu.edu/pubweb/ esslinge/chcklst/chcklst.htm

FINK, B. 1904. A lichen society of a sandstone riprap. Botanical Gazette 38:265-284.

Freebury, C.E. 2014. Lichens and lichenicolous fungi of Grasslands National Park (Saskatchewan, Canada). Opuscula Philolichenum 13:102-121.

Gilbert, O.I. 1980. A lichen flora of Northumberland. Lichenologist 12:325-395.

HALE, M.E. 1982. Lichens as bioindicators and monitors of air pollution in the Flat Tops Wilderness Area, Colorado. Final Report, U.S. Forest Service Contract No. OM RFP R2-81-SP35. 22 November 1982.

Hirschfeld, S. 2013a. Unique geology of White Rocks. Information report to City of Boulder, Open Space and Mountain Parks.
Hinschfeld, S. 2013b. Unique geology and biota of the Niwot/Somerset White Rocks on Boulder County Parks and Open Space. Information report to City of Boulder, Open Space and Mountain Parks.

Hogan, T. 1993. A floristic survey of the Boulder Mountain Park, Boulder, Colorado. Natural History Inventory of Colorado 13, University of Colorado Museum. 63 pp.

Lendemer, J.C., R.C. Harris, and E.A. Tripp. 2013. The lichens and allied fungi of Great Smoky Mountains National Park. The New York Botanical Garden Press, Bronx, NY. 260 pp.

Lendemer, J.C., AND E.A. Tripp. 2008. Contributions to the lichen flora of North Carolina: a preliminary checklist of the lichens of Gorges State Park. Bryologist 111: $57-67$.

MacPhail, D.D., H.L. Young, and D.I. Netoff. 1970. White Rocks Natural Area Study. Unpublished manuscript, Department of Geography, University of Colorado, Boulder, CO.

McCune, B., P. Rogers, A. Ruchty, and B. Ryan. 1998. Lichen communities for forest health monitoring in Colorado, USA. Report to the USDA Forest Serve/ Forest Inventory and Analysis Program, Ogden, UT.

Netoff, D.I. 1971. Polygonal jointing in sandstone near Boulder, Colorado. Mountain Geologist 8:17-24.

Rushforth, S.R., L.L. St. Clair, J.D. Brotherson, and G.T. NEBEKER. 1982. Lichen community structure in Zion National Park. Bryologist 85:185-192.

SHowman, R.E. 1987. Macrolichen flora of Crane Hollow, Hocking County, Ohio. Ohio Journal of Science 87: $27-29$.

Shrestha, G., AND L.L. St. Clair. 2009. The lichen flora of southwestern Colorado. Evansia 26:102-123.

Shushan, S., And R.A. Anderson. 1969. Catalog of the lichens of Colorado. Bryologist 72:451-483.

SKorepa, A.C. 1973. Taxonomic and ecological studies on the lichens of southern Illinois. Doctoral dissertation, University of Tennessee, Knoxville, TN. 248 pp.

ŚLIWA, L. 2007. A revision of the Lecanora dispersa complex in North America. Polish Botanical Journal 52:1-70.

TRIPP, E.A. In press. Field guide to the lichens of White Rocks, Boulder, Colorado. University Press of Colorado.

Tripp, E.A., And J.C. Lendemer. 2015. Candelariella clarkii and Lecidea hoganii: two lichen species new to science from White Rocks Open Space, City of Boulder, Colorado. Bryologist 118:154-163.

Weber, W.A. 1949. The flora of Boulder County, Colorado. Unpublished report, University of Colorado Museum, Boulder, CO.

Weber, W.A. 1970. Letter distributed to Boulder County Long-Range Planning Commission.

Weimer, R.J. 1973. A guide to the uppermost Cretaceous stratigraphy, central Front Range, Colorado: deltaic sedimentation, growth faulting and early Laramide crustal movement. Mountain Geologist 10:53-97.

Westberg, M., C.A. Morse, and M. Wedin. 2011. Two new species of Candelariella and a key to the Candelarieales (lichenized Ascomycetes) in North America. Bryologist 114:325-334.

Will-Wolf, S., L.H. Geiser, P. Neitlich, and A.H. Reis. 2006. Forest lichen communities and environmenthow consistent are relationships across scales? Journal of Vegetation Science 17:171-184.

Received 5 March 2015

Accepted 23 May 2015 